\title{
LOW-TEMPERATURE PHASES OF INTERFACIAL WATER IN CLAY-WATER SYSTEMS
}

\author{
Duwayne M. Anderson \\ and
}

Allen R. Tice

October 1970 


\section{PREF ACE}

This report was prepared by Dr. Duwayne M. Anderson, Chief, Earth Sciences Branch, and Allen R. Tice, Engineering Technician, ESB, Research Division, U.S. Army Cold Regions Research and Engineering Laboratory.

The authors wish to thank Dr. K.F. Sterrett, Chief, Research Division, and members of the Earth Sciences Branch for their encouragement and helpful suggestions throughout the course of this work.

The report is published under DA Task 1T061102B52A02, Physics and Chemistry of Frozen Ground.

The contents of this report are not to be used for advertising, publication, or promotional purposes. Citation of trăde names does not constitute an official endorsement or approval of the use of such commercial products.

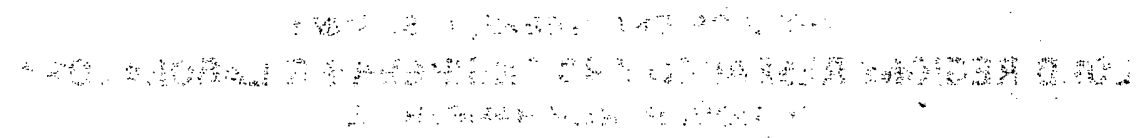




\section{CONTENTS}

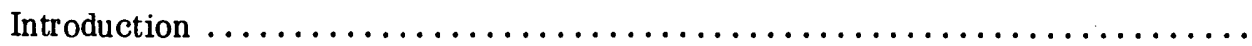

Experimental procedure $\ldots \ldots \ldots \ldots \ldots \ldots \ldots \ldots \ldots \ldots \ldots \ldots \ldots \ldots \ldots \ldots \ldots$

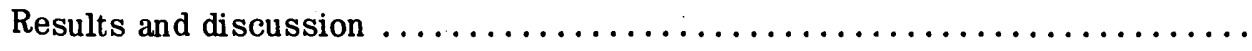

Derivation of unfrozen water contents from these results $\ldots \ldots \ldots \ldots \ldots \ldots \ldots$

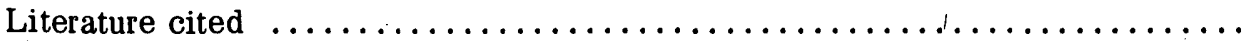

\section{ILLUSTRATIONS}

Figure

1. Low temperature differential thermal analysis curves $\ldots \ldots \ldots \ldots \ldots \ldots$

2. Doublet freezing exotherms and their shift with time during freeze-thaw cycling of $\mathrm{Na}, \mathrm{Ca}$-montmorillonite-water $\ldots \ldots \ldots \ldots \ldots \ldots \ldots \ldots$

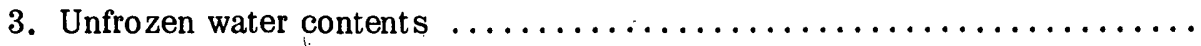

\section{TABLES}

I. Low temperature phase transition temperatures of interfacial water in frozen uni-ionic montmorillonite- and other clay-water mixtures ..........

II. Average temperatures and magnitudes of the low temperature exotherms for

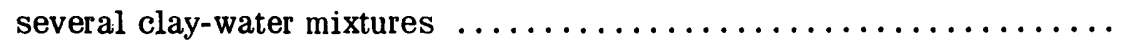




\title{
LOW-TEMPERATURE PHASES OF INTERFACIAL WATER IN CLAY-WATER SYSTEMS
}

\author{
by \\ D.M. Anderson and A.R. Tice.

\section{INTRODUCTION}

It is now widely known that when a soil-water system is frozen a significant portion of the water remains unfrozen in a liquid or semiliquid state. Because of its importance in frost heaving, heat transport, electrical conduction and shock wave transmission, the nature and properties of this unfrozen interfacial water have been a topic of continuing interest in this laboratory. ${ }^{3}{ }^{5}$ Our investigations have shown that, depending principally on temperature, this water surrounds the soil mineral grains in a zone that ranges in thickness from about 3 to $50 \mathrm{~A}$ or more. Down to about $-10^{\circ} \mathrm{C}$ its liquid-like nature is clearly evident from measurements of electrical conduction, ionic diffusion, and electrical and thermal osmosis. Nuclear magnetic resonance spectra make evident its high proton mobility down to temperatures below $-50^{\circ} \mathrm{C},{ }^{11}$ but it has not been shown at what temperature it eventually solidifies. To better define this temperature and to delineate fruitful temperature/ pressure fields for more systematic investigations by calorimetric and perhaps dilatometric techniques, we have examined several representative clay-water systems by low temperature differential thermal analysis (DTA).

Differential thermal analysis is a well known technique for locating phase transition temperatures and estimating the associated thermal energies. Recent treatments of the principles of the method and illustrations of its use are those of Barshad ${ }^{8}$ and Smothers and Chiang. ${ }^{17}$. Extension of the method to low temperatures is straightforward and involves no new principles. But only two investigations have been found in which minerals of interest in the present context were studied. Kato was the first to examine the hydrated layer lattice silicates by low temperature DTA. ${ }^{12}$ Depending on the mineral involved, he reported one and in some cases two exotherms in addition to the one associated with normal freezing of the imbibed water. These occurred at temperatures ranging from $-15^{\circ} \mathrm{C}$ to $-40^{\circ} \mathrm{C}$. Conclusions derived from these findings are discussed later in connection with the results of the present work.

Low temperature DTA has also been used in the study of frozen rocks by Dunn and Hudec. ${ }^{10}$ They reported that from 50 to $100 \%$ of the water present in their specimens of "sound rock" " was frozen at $-10^{\circ} \mathrm{C}$ and that no further evidence of freezing could be detected down to $-20^{\circ} \mathrm{C}$. In three specimens of "unsound rock," less than $50 \%$ of the water known to be present could be accounted for by measuring the heat released down to $-20^{\circ} \mathrm{C}$. And in eleven of the unsound rocks no evidence whatever of freezing was detected down to $-40^{\circ} \mathrm{C}$. They concluded that " unsoundness" in many rocks was more directly related to the quantity of unfrozen water present than to the quantity of ice formed on freezing. They did not observe low temperature exotherms corresponding to those observed by Kato in the case of the layer lattice silicates. 


\section{EXPERIMENTAL PROCEDURE}

The clays selected for investigation included kaolinite from the Dixie Rubber Pit, Bath, South Carolina; halloysite from Wagon Wheel Gap, Colorado; and uni-ionic lithium, sodium, potassium, and calcium derivatives of montmorillonite (Wyoming bentonite). The kaolinite and halloysite clays were lightly ground by mortar and pestle and used without further treatment. Wyoming bentonite was first dispersed in distilled water and allowed to stand until all particles larger than 1 micron, equivalent spherical diameter as calculated by Stokes' law, had settled out. The remaining suspension was pumped through a hydrogen-saturated and then a hydroxyl-saturated exchange-resin column. Titration of a portion of the effluent suspension at this point with $\mathrm{NaOH}$ established that exchange was complete and the absence of chloride and sulfate ions (qualitative tests with $\mathrm{AgNO}_{3}$ and $\mathrm{BaCl}_{2}$ ) provided satisfactory evidence that soluble salts had been effectively removed. The suspension was then passed through another cation resin column saturated with the desired ion. Following this treatment the suspension was concentrated by means of a pressure membrane apparatus, and stored until needed.

The DTA cell consisted of a solid stainless steel cylinder 2 in. long and 1.5 in. in diameter. Circular holes $1 / 2$ in. deep and $1 / 2$ in. in diameter designed to accept the sample and the reference material, respectively, were cut into the ends of this piece. A small hole $1 / 16$ in. in diameter communicating from the outside of the cylinder to the bottom of each sample chamber made it possible to position a No. 30 gauge copper-constantan thermocouple in the center of each chamber. The thermocouples were wired in opposition, providing a direct measurement of the differential temperature, and one of the sample holes was filled with the reference substance.

The suitability as a reference substance of a number of materials, including ice, was investigated briefly. Alumina is normally used in high temperature DTA and it was found to be a good reference material at low temperature as well, provided sufficient care was taken to exclude moisture. However, in order to avoid any possibility of confusion due to unknown surface effects, it was decided not to use a powder as the reference material. After verifying that baseline drift due to the mismatch in thermal conductivity was manageable. Wood's metal finally was selected as the reference.

The cell was fitted with $1 / 2$-in.-thick end caps secured with machine screws to confine the sample and reference material during the analyses. Except for the end caps, the cell was wrapped uniformly with nichrome resistance wire so that heat could be supplied in appropriate amounts during the warming, portion of each run. After loading, a second copper-constantan thermocouple with its reference junction in an ice bath was led in through one of the end caps and buried in the sample. The leads were connected to a strip chart recorder to provide an accurate measurement of the sample temperature. The output of the differential thermocouple assembly was passed through a d-c amplifier and displayed on a second channel of the strip chart recorder.

Water was added and mixed to bring the samples to desired water contents; several days were allowed for reequilibration before use. Immediately prior to loading, the samples were again mixed. The loaded cell, with the end caps secured, was then suspended over liquid nitrogen in a Dewar flask fitted with a Styrofoam cover. The cell was cooled at a controlled rate by stirring the air inside the Dewar with a variable speed stirrer. Cooling rates of about $2.5^{\circ} \mathrm{C} / \mathrm{min}$ were normally used. With this apparatus it was possible to obtain excellent data down to $-100^{\circ} \mathrm{C}$. 


\section{RESULTS AND DISCUSSION}

The low temperature DTA curves, adjusted to a flat base line for the several uni-ionic forms of montmorillonite and for kaolinite and halloysite, are shown in Figure 1 as a function of water content. To illustrate how the curves may be interpreted, consider the one for lithium-montmorillonite (Fig. 1a) at a water content of $0.598 \mathrm{~g} \mathrm{H}_{2} \mathrm{O} / \mathrm{g}$ clay. As the temperature was lowered at $2.5^{\circ} \mathrm{C} /$ min, an exotherm was observed at $-6^{\circ} \mathrm{C}$, continuing to about $-10^{\circ} \mathrm{C}$. At about $-38^{\circ} \mathrm{C}$ a smaller exotherm can be seen and at about $-47^{\circ} \mathrm{C}$ a third small exotherm appears. Examination of the curves corresponding to lower sample water contents shows that the temperature of nucleation and the intensity of the first exotherm diminish continually with decreasing temperature. This exotherm corresponds to the heat evolved on initial freezing of the sample. Allowing for about five degrees of undercooling, it can be shown that the lowering of initial nucleation temperature with diminishing water content apparent from the first exotherm in Figure 1 follows the general law of the freezing point depression. ${ }^{14}$ The exotherms at lower temperatures seen in these figures, however, do not change significantly with the sample water content (provided only that the sample water content is equal to or higher than that corresponding to a monolayer coverage of the mineral surface). These exotherms rather are related to clay lattice type; this is illustrated in Table I. Note that in Table I the temperature of initial nucleation is omitted to facilitate comparison of the secondary exotherm temperatures. Potassium-montmorillonite is unique among the uni-ionic derivatives of montmorillonite in that it gives three distinct low temperature exotherms. The 2:1 layer lattice minerals give more than one exotherm and are thus distinguished from the 1:1 minerals whicil give only one. There also seem to be significant differences in the secondary phase transition temperatures among the clay minerals so far examined.

Table I. Low temperature phase transition temperatures of interfacial water in frozen uni-ionic montmorillonite- and other clay-water mixtures.

Average of eight determinations except average of five for kaolinite and halloysite in this investigation.

\begin{tabular}{lcccc}
\multicolumn{1}{c}{ Clay } & \multicolumn{4}{c}{ Transition temperature $\left({ }^{\circ} \mathrm{C}\right)$} \\
\cline { 2 - 5 } & \multicolumn{1}{c}{ Data of Kato } & This study \\
\hline Li-montmorillonite & -10.0 & -20.5 & -37 & -46 \\
Na-montmorillonite & -10.0 & -26.5 & -37 & -46 \\
K-montmorillonite & -4.5 & -24.0 & $-33,-35$ & -43 \\
Ca-montmorillonite & -9.8 & -24.0 & -36 & -42 \\
Kaolinite & & none observed & -37 & \\
Halloysite & & none observed & -39 & \\
\hline
\end{tabular}

Table I also contains the data of Kato. When comparisons are made, discrepancies appear. In seeking an explanation, it is important to recall that in Kato's investigation the clays were studied at a single, relatively low water content. Each sample was exposed for one week to an . atmosphere saturated with water vapor, after which they were removed and placed in the DTA cell for analysis. Immediately before the analysis was begun, about $0.1 \mathrm{~g} \mathrm{H}_{2} \mathrm{O} / \mathrm{g}$ clay was added to the sample but no time was allowed for equilibration. In the case of the various uni-ionic derivatives of montmorillonite, Kato observed three exotherms: the first at about $-4^{\circ} \mathrm{C}$ (not shown in 


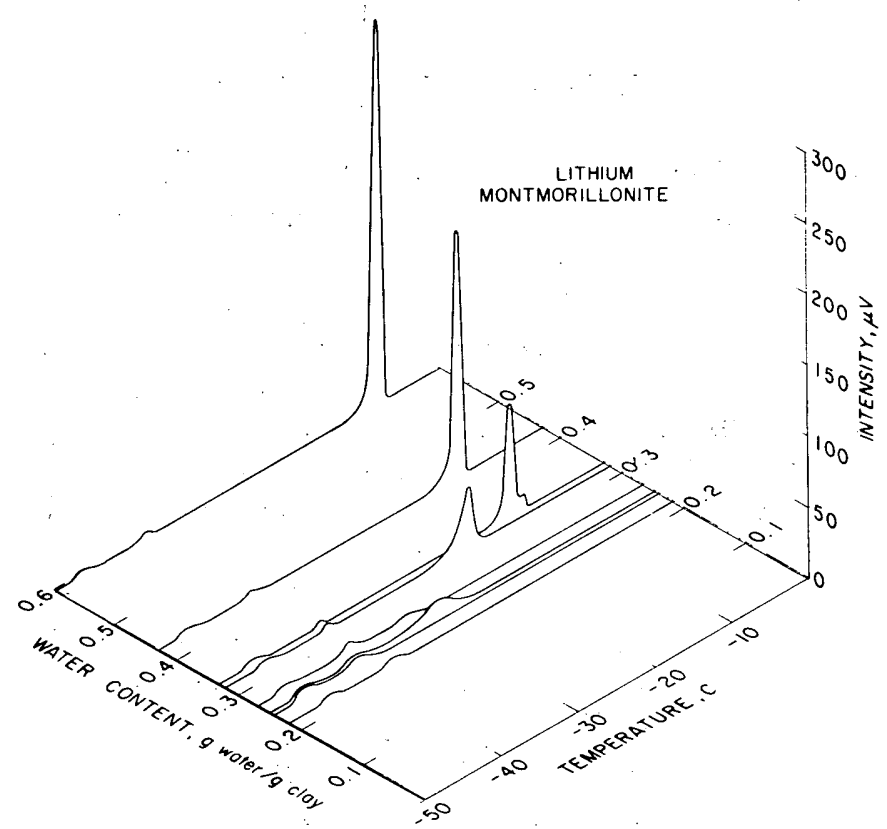

a. Lithium-montmorillonite.

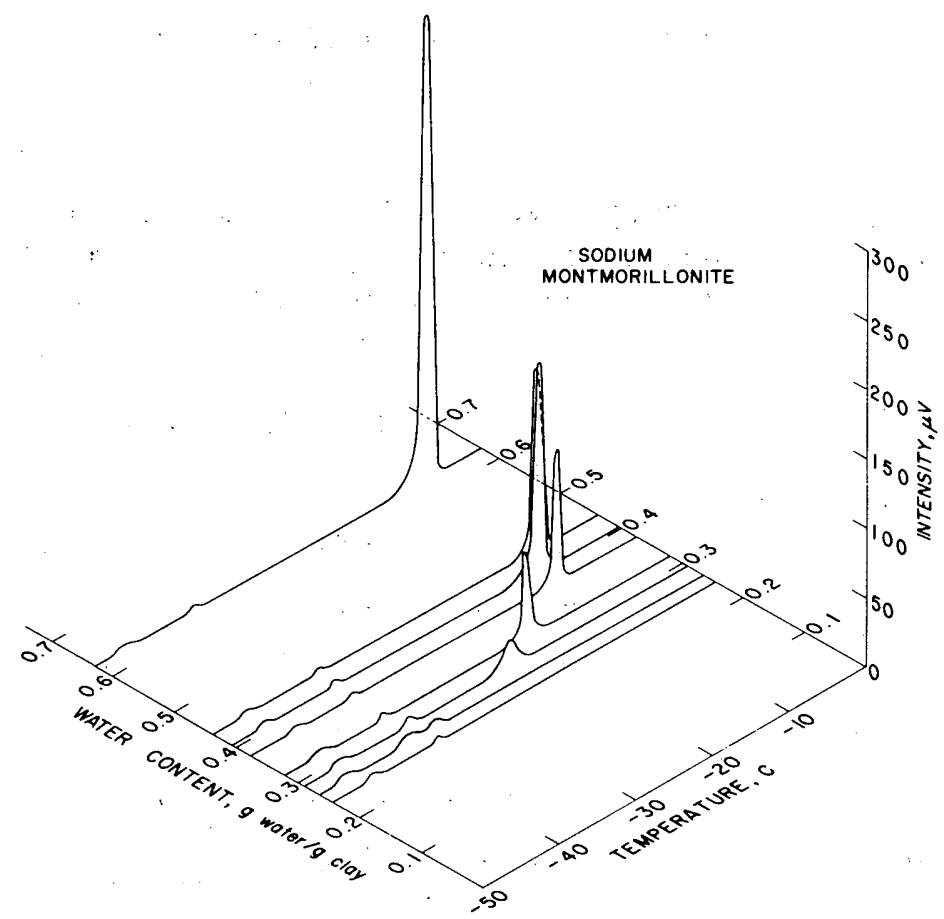

b. Sodium-montmorillonite.

Figure 1. Low temperature differential thermal analysis curves. 


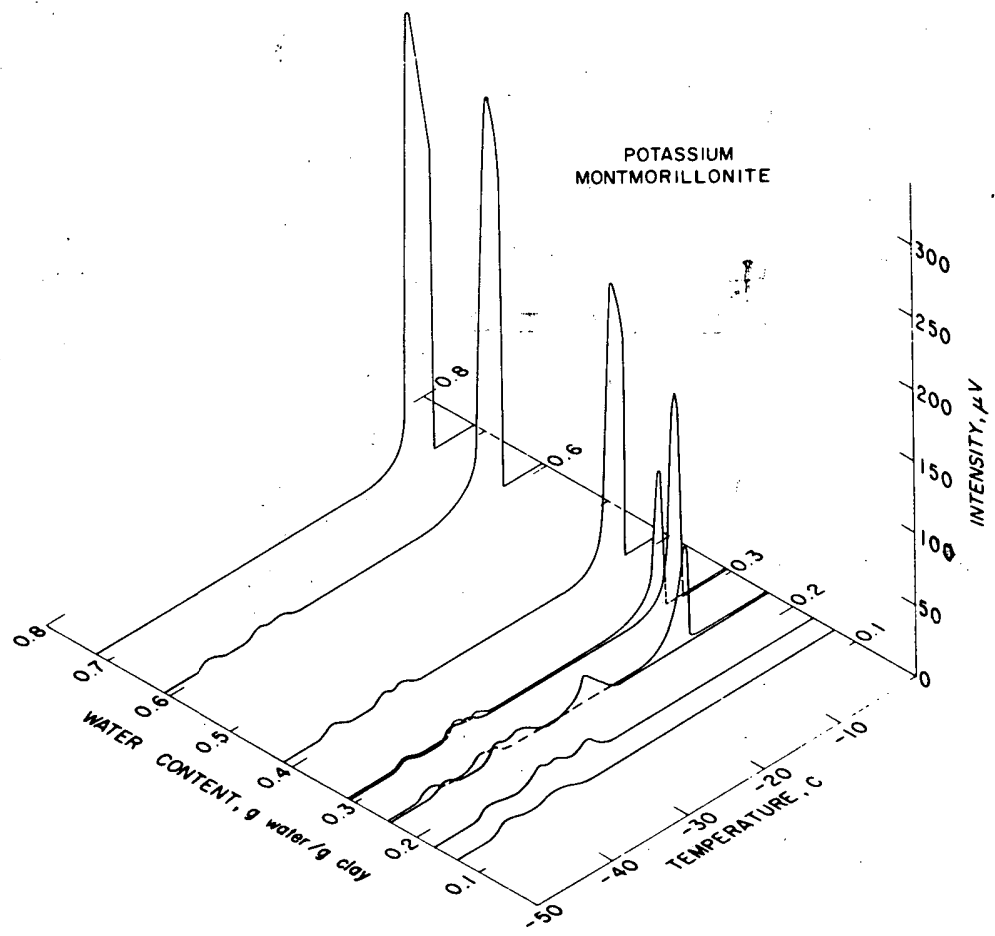

c. Potassium-montmorillonite.

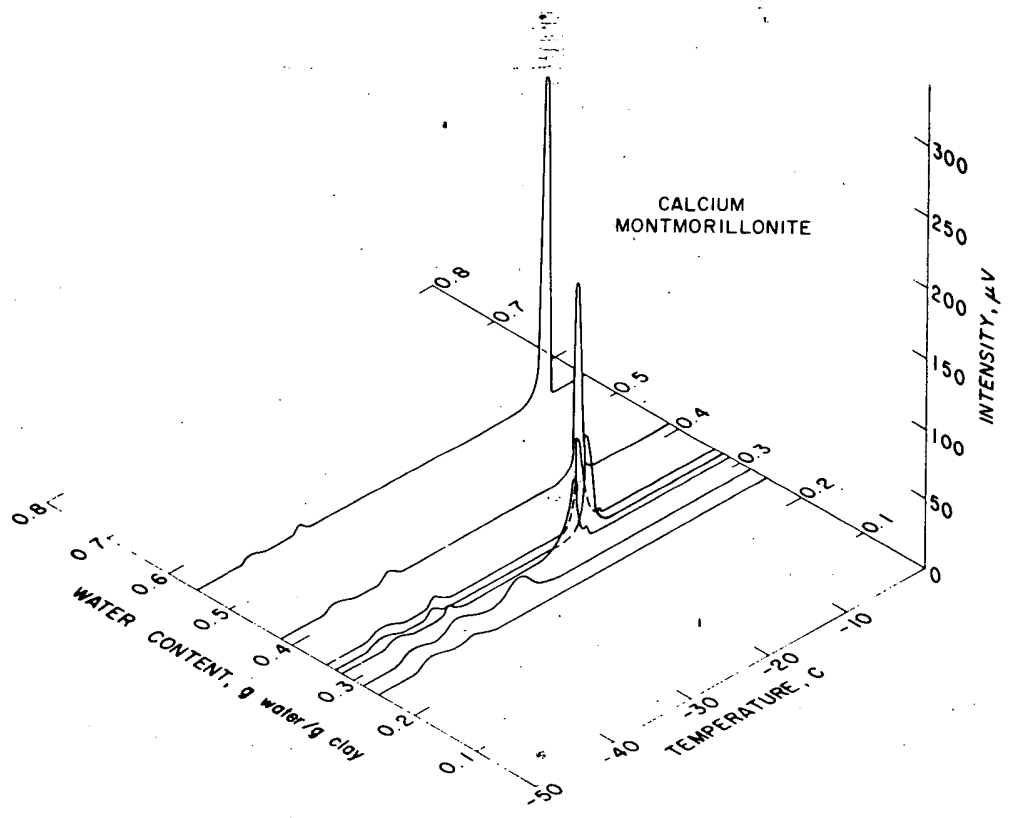

d. Calcium-montmorillonite.

Figure 1 (Cont'd). 


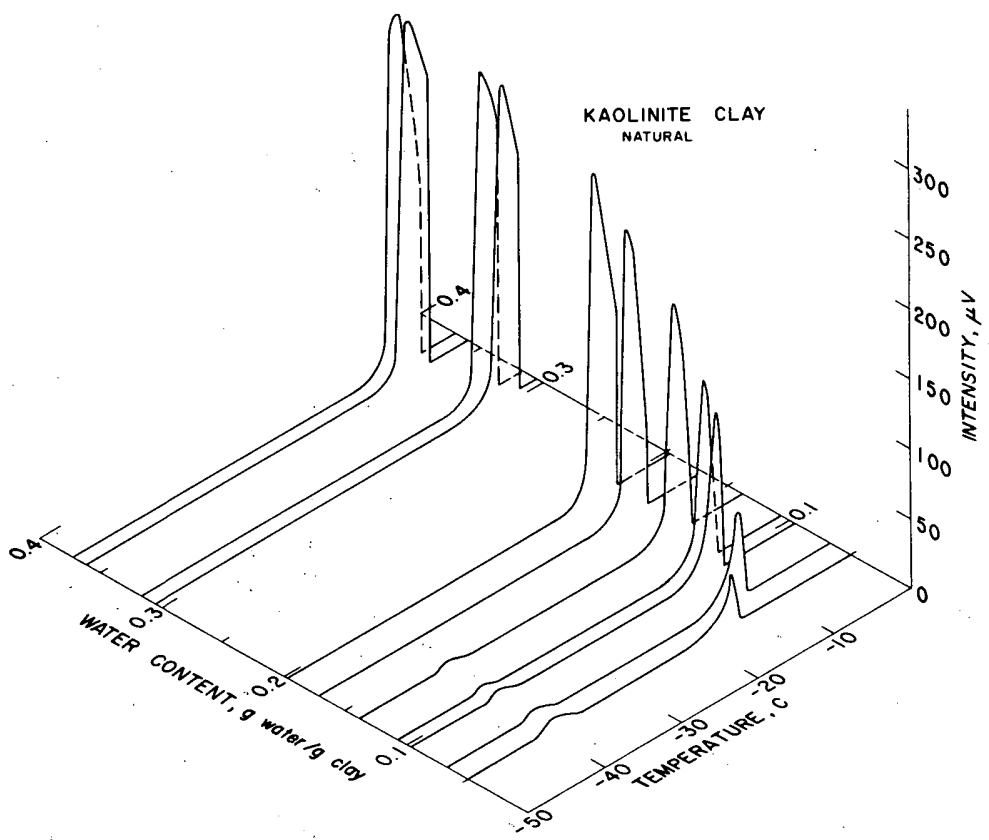

e. Kaolinite.

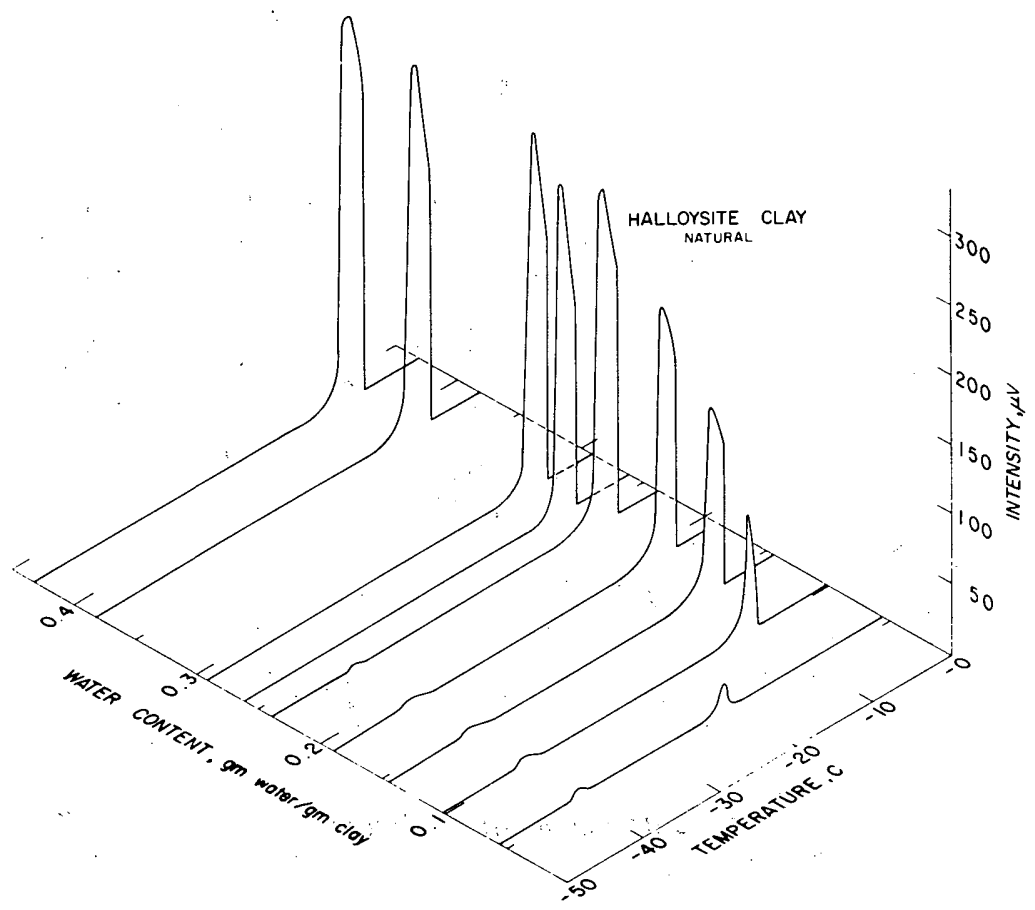

f. Halloysite.

Figure 1 (Cont'd). Low temperature differential thermal analysis curves. 
Table I), the second at about $-10^{\circ} \mathrm{C}$ (except for $\mathrm{K}$-montmorillonite which is reported at $-4.5^{\circ} \mathrm{C}$ ), and the third at -20 to $-28^{\circ} \mathrm{C}$. He attributed the first exotherm to the freezing of the "mechanically mixed" water that was added immediately before the analysis, the second to the freezing of an "absorbed, liquid-like layer," and the third to changes in the state of the interlamellar water. In the case of kaolinite he observed only one exotherm at about $-5^{\circ} \mathrm{C}$ which was attributed to the freezing of "mechanically mixed". water.

This is not the only interpretation possible, however. In view of the fact that time was not allowed for equilibration of the added water, the exotherms might equally well be held to result from successive freezing of separate domains within the sample, each having a different water content, a different interlamellar spacing, and, consequently, different nucleation temperatures. This interpretation is interesting in that it requires the occurrence of independent nucleating events in the domains of differing water content. Two observations may be adduced in support of this interpretation. If one plots the nucleation temperature for the first exotherms shown in Figure 1 versus sample water content, a logarithmic relationship appears which, as mentioned above, is displaced from but corresponds roughly to the law of the freezing point depression. When the temperature of the third exotherm observed by Kato (the second column under Data of Kato in Table I) for his uni-ionic montmorillonite clays is put on these plots, using the uniform sample water content prevailing before addition of the final increment, the data plot together on the same logarithmic curve. We conclude, therefore, that the temperature of the first exotherm of this study corresponds to Kato's third and, further, that Kato did not observe the secondary low temperature exotherms.

This conclusion is further substantiated by the series of DTA curves given by a mixed Na.Ca montmorillonite (Fig. 2). The sample was treated in a manner similar to Kato's in that a final increment of water was added immediately before the first cooling curve was taken. Then the sample was warmed and allowed to stand undisturbed for 43 minutes, after which a second cooling curve was taken. After the sample had warmed and stood 9 minutes a third determination was made and so on as illustrated in Figure 2. Two primary exotherms were observed in the first curve run $\left(t_{0}\right)$, one at $-12^{\circ} \mathrm{C}$ and one at $-16^{\circ} \mathrm{C}$. In addition to those shown, the two low temperature exotherms were observed as expected at $-37^{\circ}$ and $-46^{\circ} \mathrm{C}$. Two primary exotherms were observed on the second determination $\left(t_{1}\right)$ as well, but. a noticeable shift toward a somewhat higher nucleation temperature occurred. The two exotherms merge into one in traces $t_{2}-t_{5}$ when only short intervals were permitted to elapse between successive determinations. As shown in curves $t_{6}$ and $t_{7}$ two separate exotherms were obtained after an interval of 22 hours but, as seems to be the trend established in trace $t_{2}$, the first is the smaller of the two.

It has recently been shown that freezing and thawing bring about a dramatic redistribution of water and a reorientation of particles..$^{5.6}$ Uni-ionic derivatives of montmorillonite collapse from the relatively high $d(001)$ spacings characteristic of the saturating cation and the water content first to about $19 \mathrm{~A}$ and, as the temperature is lowered further, to about $16 \mathrm{~A}$. The $16 \mathrm{Ad}(001)$ spacing, however, persists unchanged from about $-10^{\circ} \mathrm{C}$ down to liquid nitrogen temperatures. The interlamellar water expelled from between the individual expandable layers migrates out to the external pore space where it adds on to growing ice crystals. However, a portion of the water that corresponds to the $16 \mathrm{~A} \mathrm{~d}(001)$ spacing remains in the interlamellar space down to the lowest temperatures. On warming, there is a progressive melting of the ice and a return of water to interlamellar locations.

Although each uni-ionic montmorillonite exhibited distinctive characteristics, this description encompasses the general behavior of all the 2:1 lattice clays studied. Figure 2, then, is consistent with the existence of domains of different lattice spacings, each having a characteristic ice nucleation temperature because of water being caught in various stages of redistribution within the sample. It is believed that all the exotherms observed by Kato are accounted for by this phenomenon. 


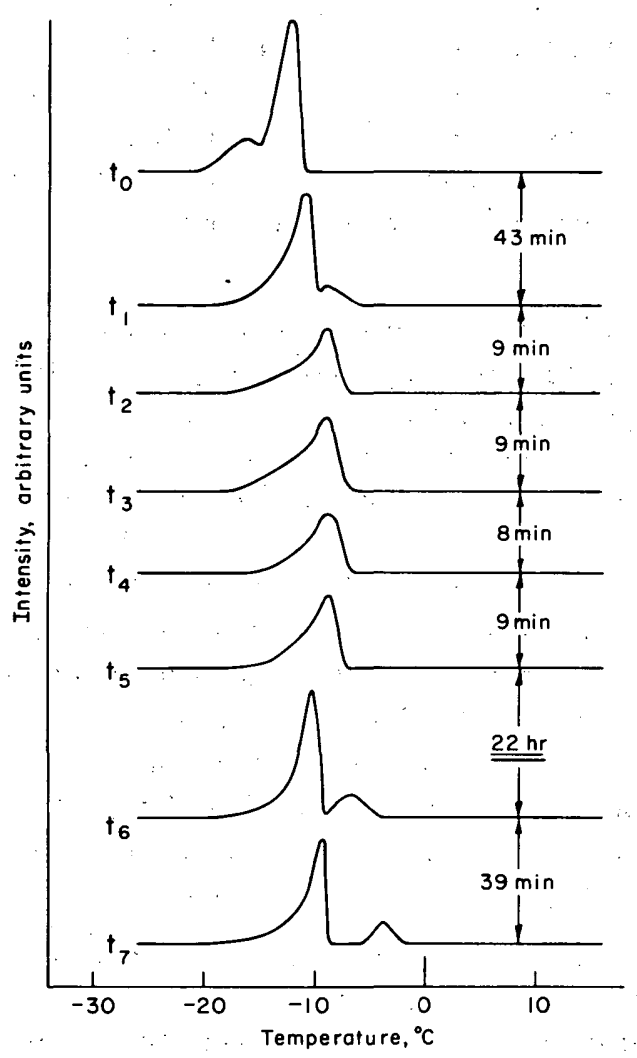

Figure 2. Doublet freezing exotherms and their shift with time during freeze-thaw cycling of $\mathrm{Na}, \mathrm{Ca}$-montmorillonite-water mixture.
Accordingly the small pips on the primary exotherms for lithium- and calcium-montmorillonite at water contents between 30 and $40 \%$ (Fig. 1a and 1d) thus are attributable to the presence of a relatively small number of domains having lattice spacing somewhat larger than that prevailing throughout the bulk of the sample specimen.

A consistent interpretation of the curves shown in Figure 1 and the data of Kato is as follows. All the exotherms observed above $-30^{\circ} \mathrm{C}$ correspond to water freezing to ice in pores and interstices exterior to the interlamellar space. The temperatures at which the exotherms appear are related to nucleation events which in turn depend upon the state of the water throughout the sample. Whenever domains of differing water content or differing lattice spacings exist, or if there are different exchangeable ion populations, exotherms corresponding to nucleation and freezing in these domains may be observed at characteristic, but so far unpredictable, temperatures in this range. In general, the more intimately the water is associated with the mineral surfaces and its exchangeable ions, the lower is its temperature of nucleation, in accordance with the law of the freezing point depression.

The low temperature exotherms no doubt correspond to the solidification of the interfacial water in the frozen clays. In the case of montmorillonite, two types of interfacial water can be differentiated: that bounded on both sides by silicate surfaces in the $6 \mathrm{~A}$ interlamellar space, and that external to the particle, bounded by a silicate surface on the one hand and by ice on the other. In addition; there is the possibility of grain boundary water in the polycrystalline ice, but for a reason which will become evident this category of water probably does not contribute significantly to these DTA curves. In the case of the two non-expanding minerals kaolinite and halloysite no interlamellar space is accessible to water and only the interfacial water associated with the external mineral surfaces is involved. Only one exotherm was observed in the case of the two non-expanding minerals; but at least two were observed in the case of the expanding minerals. This leads to the conclusion that solidification of the interlamellar water and the interfacial water associated with external surfaces occurs at different temperatures. Water external to the interlamellar space is common to all the minerals. And since the low temperature exotherm common to all occurs in the temperature range from $-35^{\circ}$ to $-40^{\circ} \mathrm{C}$, we infer that solidification of the interfacial water occurs first at external particle surfaces where the water is bounded on one side by ice. Solidification of the interlamellar water, according to this interpretation, occurs at $-40^{\circ}$ to $-50^{\circ} \mathrm{C}$.

Potassium-montmorillonite (Fig. 1c) yields three low temperature exotherms, two of which, according to the foregoing, must be ascribed to phase changes in the interfacial water external to the interlamellar space. It may be speculated that the two external domains are a consequence of a peculiar stacking or packing geometry since the three exotherms are observed only at water contents above $0.15 \mathrm{~g} \mathrm{H}_{2} \mathrm{O} / \mathrm{g}$ clay; however, this explanation is far from certain. In interpreting the 
low temperature exotherms one ought to bear in mind that the temperature range $-30^{\circ}$ to $-50^{\circ} \mathrm{C}$ embraces the eutectic temperature of a wide variety of aqueous salt solutions. The possibility that the partial dehydration of ions and charge centers might in some way be involved in the low temperature exotherms also exists.

In th: case of kaolinite and halloysite at water contents exceeding about $0.15 \mathrm{~g} \mathrm{H}_{2} \mathrm{O} / \mathrm{g}$ clay, the low temperature exotherms were not observed. This can be explained as follows: in the apparatus used, the sample size was small (about $5 \mathrm{~g}$ ) and fixed; so that increasing the water content brought about a concomitant decrease in the amount of clay present. Qbviously, this resulted in a smaller total surface area in the sample and, hence, a decrease in quantity of the interfacial water present. At the higher water contents in the kaolinite-water system the total amount of interfacial water present became too small to produce a detectable signal. The specific surface area of montmorillonite is about ten times greater than that of kaolinite or halloysite so that if the above explanation holds one would expect the same effect in montmorillonite only above $1.5 \mathrm{~g} \mathrm{H}_{2} \mathrm{O} / \mathrm{g}$ clay. Since this water content was never exceeded, this explains why the low temperature exotherms were observed in the montmorillonite-water systems at the highest water contents examined. Finally, it may be pointed out that the crystallite size of the ice formed in these clay-water systems is large, and hence the grain boundary surface area is small, in comparison with the clay crystallites. Also, the total surface area of the kaolinite and halloysite samples was so small as to yield marginally detectable low temperature exotherms at high water contents. Therefore it is not surprising that phase changes in the grain boundary water of polycrystalline ice, if they occur, were not detected in this investigation.

\section{DERIVATION OF UNFROZEN WATER CONTENTS FROM THESE RESULTS}

Determinations of the amount of unfrozen water remaining in frozen earth materials have been accomplished by the dilatometer method, ${ }^{9}$ the calorimetric method, ${ }^{15}{ }^{13}{ }^{18}$ an X-ray diffraction method, ${ }^{6}$ and a method derived from heat capacity measurements. ${ }^{2}$ Because the clay-adsorbed water has a density slightly less than that of pure water in bulk, ${ }^{7}$ the dilatometer method yields values for the quantity of unfrozen water that tend to be too high. Likewise, because the computations require the assumption that the specific heat and the latent heat of freezing the clay-adsorbed water are the same as for pure water in bulk, the calorimetric method as usually employed also yields values that are probably too high. ${ }^{12}$ The X-ray diffraction method is applicable only to mixtures with water of 2:1 expanding lattice clay minerals. Because the method cannot account for the possible existence of unfrozen water outside the interlamellar space, it may underestimate the unfrozen water content. In general, unfrozen water contents for similar samples obtained by the three methods deviate as expected; the higher values result from the dilatometer and calorimeter methods and lower values result from the X-ray diffraction method. Values obtained by the method derived from heat capacity measurements are slightly higher but in good agreement with those resulting from the X-ray diffraction method. For sodium montmorillonite at $-5^{\circ}$ and $-10^{\circ} \mathrm{C}$ the values obtained by the specific heat method were 0.4 and $0.3 \mathrm{~g} \mathrm{H}_{2} \mathrm{O} / \mathrm{g}$ clay, respectively. These data are in good agreement with the data of Nersesova and. Tsytovich for the sodium montmorillonite used in their investigation $\mathrm{s}^{16}$ and are also in accord with an estimate derived from a nuclear magnetic resonance study by $\mathrm{Wu}^{19}$

The data of Figure 1 provide another means of estimating the unfrozen water content of the samples at the temperature of initial nucleation. The first exotherms of Figure 1 result from the freezing of the portion of water $\left(W_{T}-W_{u}\right)$, where $W_{T}$ is the total sample water content and $W_{u}$ is the unfrozen water content. First, consider the sample as though it were thermally uncoupled from 
its surroundings; freezing liberates the latent heat of fusion $L$, and causes a rise in sample temperature of

$$
\theta=\frac{\left(W_{\mathrm{T}}-W_{\mathrm{u}}\right) L}{C}
$$

In eq $1, \theta$ is the sample temperature rise and $C$ is the mean specific heat of the sample. Recall that Figure 1 contains the relationship between $\theta$. (in arbitrary intensity units) and total sample water content. From eq 1 it is apparent that when $\theta=0$

$$
W_{\mathrm{T}}=W_{\mathbf{u}} \cdot
$$

Thus, to a first approximation, the unfrozen water content is obtained by determining the water content at which $\theta$ for the first exotherm becomes zero. Since eq 1 does not account for all the processes involved in the evolution and disposition of energy within the DTA cell, however, it is well to examine the conclusion of eq 2 somewhat further.

For a DTA sample holder with a sample at temperature $T_{\mathrm{s}}$, a total heat capacity of sample and its surrounding container of $C_{\mathrm{s}}$, a thermal resistance $R$ between sample and its heat source (or sink) which is at temperature $T_{p}$, the conservation of energy requires that

$$
L \frac{d\left(W_{\mathrm{T}}-W_{\mathrm{u}}\right)}{d t}=C_{\mathrm{s}} \frac{d T_{\mathrm{s}}}{d t}-\frac{\left(T_{\mathrm{s}}-T_{\mathrm{p}}\right)}{R} .
$$

The term on the left of eq 3 gives the rate of energy release generated by a phase change occurring within the sample (note that the ice content $W_{\mathrm{I}}=\left(W_{\mathrm{T}}-W_{\mathrm{u}}\right)$ is initially zero). The first term on the right-hand side accounts for the energy used to heat the sample and its container and the second term gives the rate of heat lost to the surroundings, assuming Newton's law of cooling. A similar equation developed for the reference cell combined with eq 3 yields

$$
\theta=R L \frac{d\left(W_{\mathrm{T}}-W_{\mathrm{u}}\right)}{d t}-R\left(C_{\mathrm{s}}-C_{\mathrm{r}}\right) \frac{d T r}{d t}-R C_{\mathrm{s}} \frac{d \dot{\theta}}{d t}
$$

Integrating eq 4 over an arbitrary temperature-time interval corresponding to what might be expected for the first freezing exotherm yields

$$
\theta \Delta t=R L\left(W_{\mathrm{T}}-W_{\mathrm{u}}\right)-R\left(C_{\mathrm{s}}-C_{\mathrm{r}}\right) \Delta T_{\mathrm{r}}-R C_{\mathrm{s}} \theta
$$

The first term on the right-hand side contains the heat involved in the phase change, if it occurs; the second term represents the baseline shift due to a mismatch of the specific heats of the sample and reference materials and the last term represents the thermal lag in the system. Now when the baseline shift is measured and subtracted from the curves, as was done in preparing Figure 1, the second term becomes negligible. Furthermore, when $\theta$ is zero, there is no thermal lag and the third term vanishes; this leaves

$$
\left(W_{\mathbf{T}}-W_{\mathbf{u}}\right)=0
$$

the same result as given by eq 2 . Thus, it is established that determining the water content at which the sample yields no exotherm due to the normal freezing of the imbibed water is equivalent 
to determining the unfrozen water content $W_{\mathrm{u}}$ of the sample in the temperature range $-5^{\circ}$ to $-10^{\circ} \mathrm{C}$, assuming, of course, that $W_{\mathrm{u}}$ does not depend sensitively on the total sample water content. This assumption has been justified elsewhere. ${ }^{25} 6$ The determination is accomplished conveniently by extrapolating plots of total sample water content versus intensity of the first exotherm of the DTA curves as is done in Figure 3. The intercepts give the estimates of $W_{\mathrm{u}}$. The results, in percent by weight, are: lithium-montmorillonite, $24.8 \%$; sodium-montmorillonite, $26.3 \%$; potassium-montmorillonite, $14.3 \%$; calcium-montmorillonite, $25.1 \%$; halloysite, $3.6 \%$; and kaolinite, $2.4 \%$. These values are in excellent agreement with those reported elsewhere for these minerals. ${ }^{216}$

Further analysis of the exotherms shown in Figure 1 yields additional interesting conclusions. When the areas of the low temperature exotherms are compared to the areas of the exotherms corresponding to the first freezing, it is possible to derive a proportionality constant that relates the quantities of heat involved. For example, in the case of Na-montmorillonite at $29.1 \%$ and $32.0 \%$, the areas under the first exotherm were measured on the original plots and found to be $2.41 \mathrm{~cm}^{2}$ and $6.32 \mathrm{~cm}^{2}$, respectively. The difference in water content in this instance is $0.029 \mathrm{~g} / \mathrm{g}$ dry clay. Thus, since the sample consisted of $1 \pm 0.1 \mathrm{~g}$ dry clay, it appears that the difference in the two areas, namely $3.91 \mathrm{~cm}^{2}$, corresponds to the evolution of approximately $2.3 \mathrm{cal}\left(0.029 \mathrm{~g} \mathrm{H}_{2} \mathrm{O} \times 79.71 \mathrm{cal} / \mathrm{g}\right)$. The areas under the two low temperature exotherms for the curve at $32.0 \%$ water were found to be $0.25 \mathrm{~cm}^{2}$ and $0.31 \mathrm{~cm}^{2}$ and therefore correspond to the evolution of approximately $0.15 \mathrm{cal}$ and $0.18 \mathrm{cal}$, respectively. When similar calculations are made and averaged for the other curves of Figure 1, Table II is obtained.

Table II. Average temperatures and magnitudes of the low temperature exotherms for several clay-water mixtures.

\begin{tabular}{|c|c|c|c|c|c|c|}
\hline Clay & $\begin{array}{l}\text { Temp } \\
\left({ }^{\circ} \mathrm{C}\right)\end{array}$ & $\begin{array}{c}\text { Mag } \\
\text { (cal) }\end{array}$ & $\begin{array}{l}\text { Temp } \\
\left({ }^{\circ} \mathrm{C}\right) \\
\end{array}$ & $\begin{array}{l}\text { Mag } \\
\text { (cal) }\end{array}$ & $\begin{array}{l}\text { Temp } \\
\left({ }^{\circ} \mathrm{C}\right)\end{array}$ & $\begin{array}{r}\text { Mag } \\
\text { (cal) } \\
\end{array}$ \\
\hline Li-montmorillonite & & & -37.5 & 0.10 & -45.5 & 0.17 \\
\hline Na-montmorillonite & & & -36.8 & 0.16 & -45.6 & 0.20 \\
\hline $\mathrm{K}$-montmorillonite & -34.5 & 0.35 & -36.5 & 0.35 & -43.1 & 0.33 \\
\hline $\mathrm{Ca}$-montmorillonite & & & -36.8 & 0.11 & -43.0 & 0.14 \\
\hline Kaolinite & & & -38.4 & 0.24 & & \\
\hline Halloy si te & & & -39.4 & 0.18 & & \\
\hline
\end{tabular}

If, as suggested earlier, the low temperature exotherms correspond to the solidification of the unfrozen interfacial water, it is possible to draw some conclusions regarding the latent heat involved in the phase changes. Taking the unfrozen water contents of Figure 3 and dividing them into the sums of the Magnitude columns of Table II for each clay yields $1.1,1.4,7.2,1.0,10.0$ and $5.0 \mathrm{cal} / \mathrm{g}$ for the latent heat of phase change of the interfacial water in lithium-, sodium-, potassium-, and calcium-montmorillonite, kaolinite and halloysite, respectively,

It has been established elsewhere that at water contents comparable to the unfrozen water contents of interest here, the latent heat of freezing the interfacial water in montmorillonite-water mixtures to ice is less than that of pure water by a considerable margin. ${ }^{1}$ In the vicinity of $0^{\circ} \mathrm{C}$, the latent heat of freezing begins to depart significantly from that of pure water at a clay water content of $30 \%$. It declines to zero and goes progressively more negative at about $9 \%$, signifying that about $0.09 \mathrm{~g} \mathrm{H}_{2} \mathrm{O} / \mathrm{g}$ clay is already in a thermodynamic state, that is, more stable than ice. 


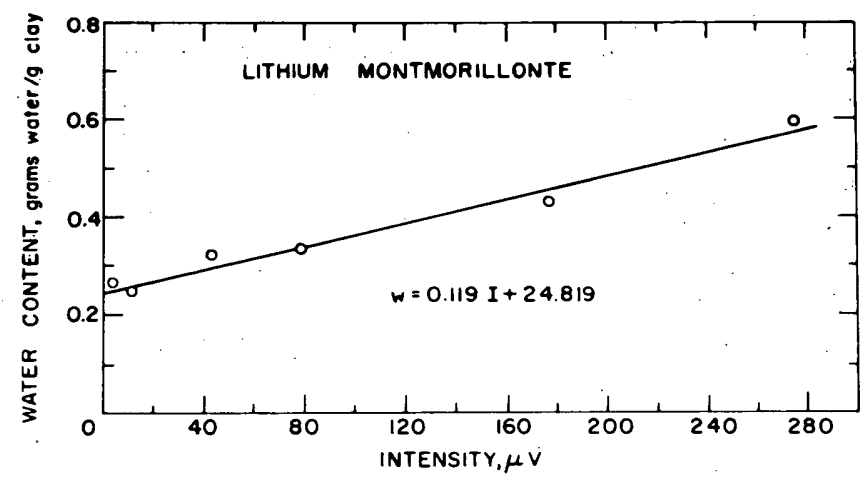

a. Lithium-montmorillonite.

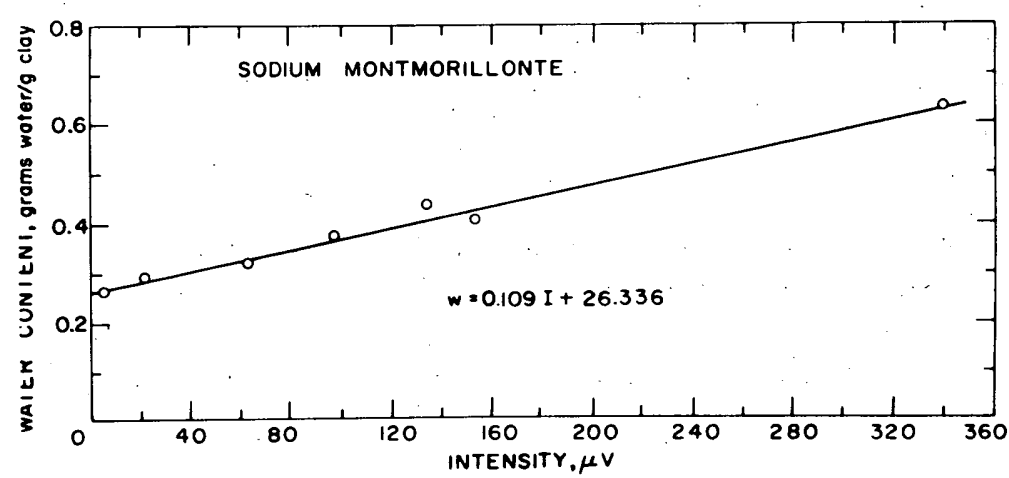

b. Sodium-montmorillonite.

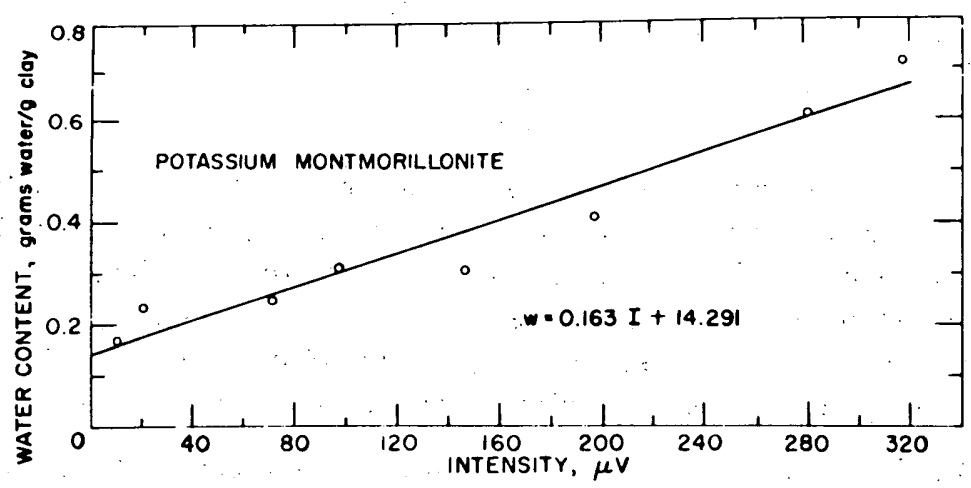

c. Potassium-montmorillonite.

Figure 3. Unfrozen water contents. 


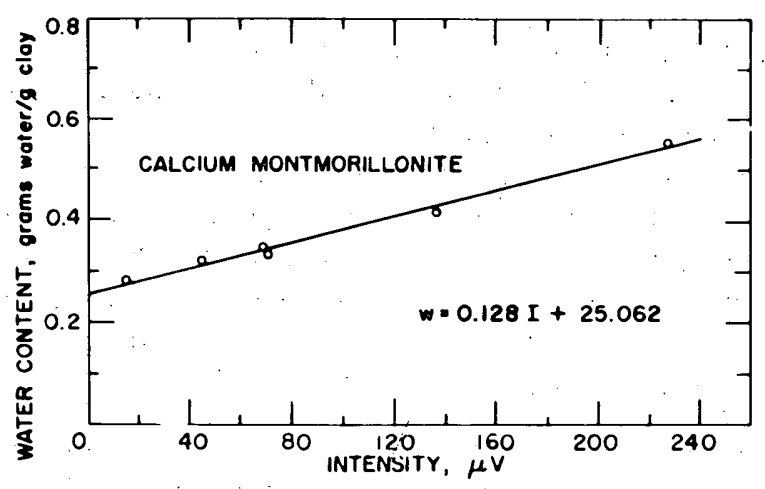

d. Cálcium-montmorillonite.

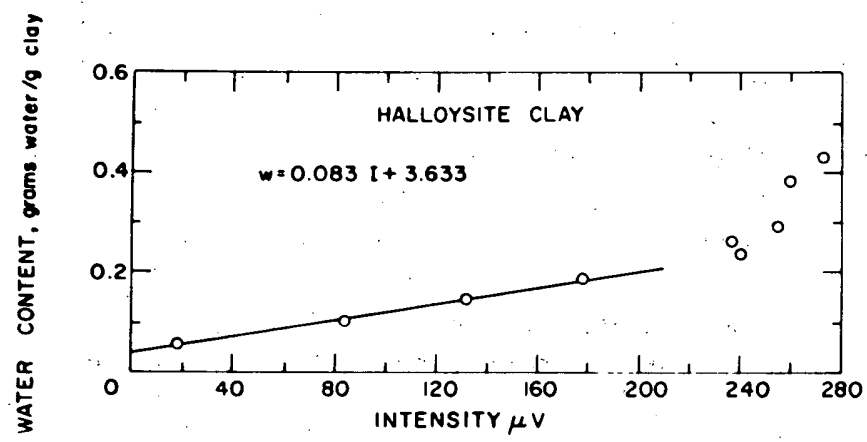

e. Halloysite.

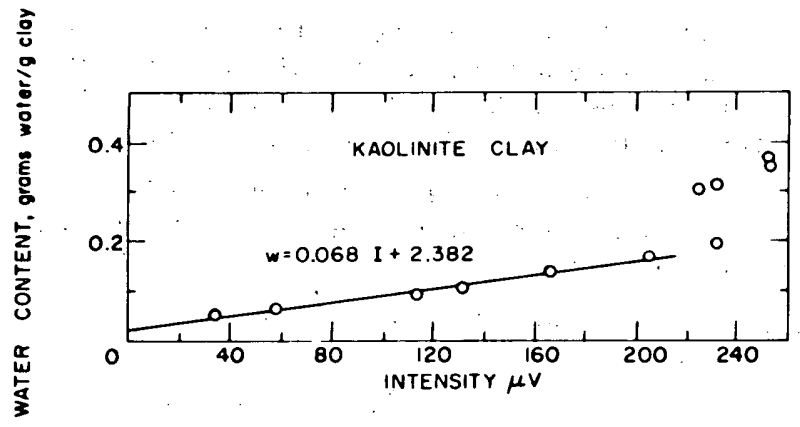

t. Kaolinite.

Figure 3 (Cont'd). 


\section{LOW-TEMPERATURE PHASES OF INTERF ACIAL WATER IN CLAY-WATER SYSTEMS}

Working from an illustration of this relationship (Figure 1 of reference 10) it appears that freezing the increment of interfacial water corresponding to a change in $W_{u}$ of $2.9 \%$ to $9 \%$, if it occurred near $0^{\circ} \mathrm{C}$, would be expected to liberate about 5.5 cal. (Data that would permit a similar calculation that would apply at -30 to $50^{\circ} \mathrm{C}$ are not available.) The total heat involved in the two low temperature exotherms for sodium montmorillonite is only about $0.36 \mathrm{cal}$, considerably less than expected even when allowance is made for the expected reduction in the latent heat of freezing the unfrozen interfacial water. Two alternative conclusions are therefore possible: either the latent heat of freezing is less at $-30^{\circ}$ to $-50^{\circ} \mathrm{C}$ than that predicted near $0^{\circ} \mathrm{C}$, or the quantity of water undergoing a phase change is smaller than expected.

It might be suggested that the low temperature phase changes do not correspond to a freezing of the interfacial water to ice but to a conversion to another, possibly unknown form. Although the data do not rule out this possibility, there is an observation that argues strongly against it. Whereas all the curves shown in Figure 1 were reproduced many times and repeated freeze-thaw cycles al ways revealed the low temperature exotherms on cooling, corresponding endotherms were never detected during the warming portion of the cycle. Only the endotherms corresponding to the melting of ice were observed. As indicated earlier ${ }^{5}$ and shown in Figure 2, extensive migration of water from interlamellar and interfacial zones occurs during freezing. The movement of unfrozen interfacial water to growing ice crystals is apparently continual, although the stepwise collapse of montmorillonite ${ }^{5}$ indicates that the water sometimes may be released in bursts, as the temperature is lowered. The process is not reversible on warming, however, because the water having been transformed to the solid state will not melt and be redistributed rapidly until the temperature is raised to about $-5^{\circ} \mathrm{C}$ or above. This probably accounts for the failure to observe low temperature endotherms on warming the specimens. The two alternative conclusions offered in the preceding paragraph remain, then, and present evidence is not sufficient to distinguish between them.

\section{LITERATURE CITED}

1. Anderson, D.M. (1963) The latent heat of freezing soil wáter. Proceedings of the 1st Permafrost International Conference, NRC-NAS Pub. No. 1287, p. 238-239.

2. (1966) Phase composition of frozen montmorillonite-water mixtures from heat capacity measurements. Soil Science Society of America Proceedings, vol. 30, p. 670-675. Also U.S. Army Cold Regions Research and Engineering Lạporatory (USA CRREL) Research Report 218, 1967 (AD 656601).

3. (1967) The interface between ice and silicate surfaces. Journal of Colloid and Interface Science, vol. 25, p. 174-191. Also USA CRREL Research Report 219 (AD 653612).

4. Gaffney, E.S. and Low, P.F.' (1967) Frost phenomena on mars. Science, vol. 155 , p. $319-322$.

5. Anderson, D.M. and Hoekstra, P. (1965a) Migration of interlamellär water during freezing and thawing. Soil Science Society of America Proceedings, vol. 29, p. 498-504.

6. (1965b) Migration of interlamellar water during freezing and thawing of Wyoming bentonite. USA CRREL Research Report 192.

7. Anderson, D.M. and Low, P.F. (1958) The density of water adsorbed by lithium-, sodium-, and potassium-bentonite. Soil Science Society of America Proceedings, vol. 22. p. 99-103.

8. Barshad, I. (1965) Thermal analysis techniques for mineral identification and mineralogical composition. In Methods of soil analysis. Madison, Wis.: American Society of Agronomy, Inc., Part I., p. 699-742. 


\section{LITERATURE CITED (Cont'd)}

9. Buehrer, T.F. and Aldrich, D.G. (1946) Studies in soil structure: VI. Water bound by individual soil constituents as influenced by puddling. University of Arizona Technical Bulletin No. 110.

10. Dunn, J.R. and Hudec, P.P. (1966) Water, clay and rock soundness. Ohio Journal of Science, vol. 66, p. 153-168.

11. Hecht, A.M., Dupont, M. and Ducross, P. (1966) Etude des phénomenes de transport de l'eau adsorbée dans certains minéraux argileux par le résonnance magnétique nucléaire (Study of movement phenomena of adsorbed water in certain clay minerals by nuclear magnetic resonance). Bulletin de la Societé Francaise de Minéralogie et Cristallographie, vol. 89, p. 6-13.

12. Kato, C. (1959) Differential thermal analysis of clay minerals between the temperatures of $0^{\circ} \mathrm{C}$ and $-195^{\circ} \mathrm{C}$. Journal of the Ceramics Association of Japan, 67(7), p. $97 \cdot 100$.

13. Kolaian, J.H. and Low, P.F. (1963) Calorimetric determination of unfrozen water in montmorillonite pastes. Soil Science, vol. 95, p. 376-383.

14. Low, P.F., Anderson, D.M. and Hoekstra, P. (1968) Some thermodynamic relationships for soils at or below the freezing point. 1. Freezing point depression and heat capacity. Water Resources Research, vol. 4, p. 379-394. Also USA CRREL Research Report 222, Pt. 1 (AD 649729).

15. Martynov, G.A. (1956) Kalorimetricheskoi metodike opredeleniia kolichestva nezamerzshei vody $\mathrm{v}$ merzlykh gruntov (Calorimetric method of determining the amount of unfrozen water within frozen ground). Materialy $\mathrm{k}$ osnovam ucheniia o merzlykh zonakh zemnoi kory, Vol. III, p. 179-185. National Research Council of Canada, Ottawa, Technical Translation 1088.

16. Nersesova, Z.A. and Tsytovich, N.H. (1963) Unfrozen water in frozen soils. Contributions by the Russian delegation to the International Conference on Permafrost. N.A. Tsytovich, Ed., Akad Nauk SSSR. English Translation, Proceedings of the 1st Permafrost International Conference, NAS-NRC, Pub. No. 1287, p. 230-237.

17. Smothers, W.J. and Chiang, Y. (1966) Handbook of differential thermal analysis. N.Y., N.Y. Chem. Pub. Co., Inc.,

18. Williams, P.J. (1963) Specific heat and unfrozen water content of frozen soils. In Proceedings of the 1st Canadian Conference on Permafrost, National Research Council, Canada. Tech. Memo. No. 76.

19. Wu, T.H. (1964) A nuclear magnetic resonance study of water in clay. Journal of Geophysical Research, vol. 69, p. 1083-1091. 
DOCUMENT CONTROL DATA - R \& D

(Security classification of title, body of abstract and indexing ennotation must be entered when the overall report is classified) 1. ORIGINATING ACTIVITY (Cotporate author) TE. REPORT SECURITY CLASSIFICATION

U.S. Army Cold Regions Research and Engineering Laboratory Hanover, New Hampshire 03755 3. REPORT TITLE

LOW-TEMPERATURE PHASES OF INTERFACIAL WATER IN CLAY-WATER SYSTEMS

4. DESCRIPTIVE NOTES (TYPE of report and inclusive datea)

8. AUTHOR(S) (First name, middle initiel, last name)

D.M. Anderson and A.R. Tice

\begin{tabular}{|c|c|}
\hline $\begin{array}{l}\text { 6. REPORT DATE } \\
\text { OCtober } 1970\end{array}$ & $\begin{array}{c}\text { 7a. TOTAL NO. OF PAGES } \\
19\end{array}$ \\
\hline $\begin{array}{l}\text { 8. CONTRACT OR GRANT NO. } \\
\text { b. PROJECT NO. }\end{array}$ & $\begin{array}{l}\text { 9a. ORIGINATOR'S REPORT NUMBERIS) } \\
\text { Research Report } 290\end{array}$ \\
\hline $\begin{array}{l}\text { c. DA Task 1T061102B52AO2 } \\
\text { d. }\end{array}$ & $\begin{array}{l}\text { 9b. OTHER REPORT NO(S) (Any other numbers that may bo aselened } \\
\text { this report) }\end{array}$ \\
\hline
\end{tabular}

10. DISTRIBUTION STATEMENT

This document has been approved for public release and sale; its distribution is unlimited.

11. SUPPLEMENTARY NOTES

12. SPONSORING MILITARY ACTIVITY
U.S. Army Cold Regions Research
and Engineering Laboratory
Hanover, New Hampshire 03755

13. ABSTRACT

Low temperature differential thermal analyses of selected clay-water systems were made to locate important phase change temperatures and to define fruitful temperaturepressure fields for precise calorimetric investigation. In addition to an exotherm corresponding to initial freezing, one, two or three exotherms were observed between $-35^{\circ} \mathrm{C}$ and $-60^{\circ} \mathrm{C}$. The low temperature exotherms do not depend critically upon water content, but clearly they are relaced to clay mineral and exchangeable cation type. The evolution of heat in this temperature range probably corresponds to a phase change in the interfacial water.

14. Key Words:

Adsorbed water

Clay minerals

Differential thermal analysis

Frost heave

Frozen soils

Iiquid phases

Phase transformations

Soil water 